\title{
EXPERIMENTAL AND MOLECULAR MODELING INVESTIGATION OF THE REACTION BETWEEN CEFTRIAXONE AND SODIUM NITRITE. POTENTIAL MEDICAL IMPLICATIONS
}

\author{
MARINELA FLOREA ${ }^{\# *}$, CORINA CRISTINA ARAMĂ ${ }^{\#}$, ANGELA NEDELCU ${ }^{\#}$, IOANA \\ CLEMENTINA CONSTANTINESCU ${ }^{\#}$
} Department of Analytical Chemistry, "Carol Davila” University of Medicine and Pharmacy, Faculty of Pharmacy, 6 Traian
Vuia Street, 020956, Bucharest, Romania

*corresponding author: florea.marinela@gmail.com

${ }^{*}$ Authors with equal contribution

Manuscript received: January 2018

\begin{abstract}
The paper presents a new spectrophotometric method for the assay of ceftriaxone as diazonium salt and the potential medical implications of the reaction with sodium nitrite. Using $\mathrm{KBr}$ as catalyst, at $0-5^{\circ} \mathrm{C}$ and in acidic media a soluble and stable compound with an absorption maximum at $504 \mathrm{~nm}$ was obtained. The method was linear in the range $85-171 \mu \mathrm{g} / \mathrm{mL}$, with limits of detection and quantification of $2.52 \mu \mathrm{g} / \mathrm{mL}$ and $7.65 \mu \mathrm{g} / \mathrm{mL}$, respectively. For the diazonium ion, molecular modelling indicated as stabilization mechanism an internal charge transfer and resonance light scattering spectra confirmed it. The method is simple, rapid, accurate and precise, and successfully applied for the determination of ceftriaxone in pharmaceutical products. Ceftriaxone administration can lead to nephrolithiasis, the high urinary antibiotic and calcium concentrations being indicated to be the risk factors. The results of this study also indicated that the reaction of ceftriaxone with sodium nitrite could also have potential medical implications in this regard.
\end{abstract}

\section{Rezumat}

Lucrarea prezintă o nouă metodă spectrofotometrică de dozare a ceftriaxonei ca sare de diazoniu şi posibilele implicații medicale ale reacției cu nitritul de sodiu. Utilizând $\mathrm{KBr}$ drept catalizator, la $0-5^{\circ} \mathrm{C}$ și în mediu acid, s-a obținut un compus solubil şi stabil care are un maxim de absorbție la $504 \mathrm{~nm}$. Metoda este liniară pe domeniul $85-171 \mu \mathrm{g} / \mathrm{mL}$, cu limita de detecție de $2,52 \mu \mathrm{g} / \mathrm{mL}$ și limita de cuantificare de $7,65 \mu \mathrm{g} / \mathrm{mL}$. Pentru ionul diazoniu studiile de modelare moleculară au indicat că transferul de sarcină este mecanismul de stabilizare iar spectrele de difuzie de rezonanță au confirmat. Metoda este simplă, rapidă, exactă și precisă, fiind aplicată cu success la dozarea ceftriaxonei din forme farmaceutice. Administrarea de ceftriaxonă a fost asociată cu apariția nefrolitiazei, iar ca factori de risc au fost indicați concentrațiile urinare crescute de calciu și de antibiotic. Rezultatele acestui studiu indică faptul că proprietatea ceftriaxonei de a reacționa cu nitritul de sodiu se poate corela cu efectul secundar menționat.

Keywords: ceftriaxone, diazotization, resonance light scattering, molecular modeling, nephrolithiasis

\section{Introduction}

Ceftriaxone (CTX) is a third-generation cephalosporin, active against both gram-positive and gram-negative organisms, generally used for a variety of infections such as community-acquired pneumonia, meningitis and gonorrhoea [13]. Also CTX belongs to the group of well-established active substances for which have been discovered new therapeutic indications namely the anticancer efficacy in the lung cancers $[13,21]$. Tuberculosis being a widely and globally spread infectious and contagious disease, and significant number of patients having multidrug-resistant forms [18], most of the antimicrobial agents already available were tested as antituberculous agents, CTX being also studied [2]. Therapeutic advantages of CTX are its low toxicity and once-daily dosing schedule [17]. In terms of metabolization, ceftriaxone is excreted via digestive and renal pathways. About $40 \%$ to $65 \%$ of a dose is excreted in active form in urine by glomerular filtration [3].

Ceftriaxone has been associated with the development of biliary pseudolithiasis and nephrolithiasis, mainly in children $[4,15,16]$. The high urinary ceftriaxone and calcium concentrations were indicated to be the risk factors of promoting nephrolithiasis. Up to now, it is unclear if other urinary factors can be associated with ceftriaxone-induced stone formation $[5,6]$.

The interaction of CTX with sodium nitrite through its primary amino group contained on the thiazole ring was first mentioned as a colour reaction in citric acid media [23]. The proposed method is characterized by a reaction time of 1 hour, the measurements being carried out at $500 \mathrm{~nm}$. Diazonium salts are unstable compounds and susceptible to nucleophilic substitution reactions, 
even with water molecules [22]. So, by that time, the most intriguing aspects regarding the compound obtained in the reaction of CTX and sodium nitrite (assumed to be a diazonium salt) were its high stability in the soluble form and the negative results when the subsequent coupling has been tried. Authors have suggested, as the stabilization mechanism, the formation of "self-associating dimmers" based on the internal coupling reaction between starting $\beta$-lactam and its diazo product. Afterwards, visible spectrophotometric methods for the CTX analysis, based on diazotization and subsequently coupling were developed $[1,19]$. None of the methods cited used potassium bromide as catalyst [20] and all are performed at the room temperature. Also, from our knowledge, no resonance light scattering (RLS) studies are published for the analysis of CTX based on the diazotization reaction. Resonance light scattering (RLS), also known as resonance Rayleigh scattering or enhanced Rayleigh scattering is a simple, rapid and sensitive spectroscopic technique for the study of the conformational and volume changes of the molecules, especially as a consequence of an aggregation phenomena [7] and as assay method of medicines $[8,10]$. The aim of the present study was to investigate the reaction of CTX with sodium nitrite using potassium bromide as a catalyst. For the purpose, static light scattering and UV-Vis molecular absorption spectrophotometry were used. Data obtained using molecular modelling were also correlated with the experimental ones. As a result, a new visible spectrophotometric method for the assay of CTX was developed. The proposed method has applicability in pharmaceutical industry as it contributes to the completion of analytical profile of CTX [9]. Also, the potential medical implications of the process are discussed.

\section{Materials and Methods}

Ceftriaxone disodium hemi(heptahydrate) was bought from Sigma-Aldrich. Reagents of analytical purity and double distilled water were used throughout all experiments.

Appropriate amounts of CTX $1.5 \times 10^{-4} \mathrm{M}$ stock solution in water were mixed with $10 \% \mathrm{KBr}, 0.1 \mathrm{M}$ $\mathrm{HCl}$, and $0.1 \mathrm{M} \mathrm{NaNO}_{2}$. The blank solution was prepared using the same procedure, without CTX. All solutions were prepared at $0-5^{\circ} \mathrm{C}$, on ice.

$\mathrm{UV}-\mathrm{Vis}$ spectra were recorded on a Jasco V-730 spectrophotometer, in the range $700-300 \mathrm{~nm}$.

For the RLS spectra, a dual monochromator spectrofluorimeter (LS50B from Perkin Elmer, Inc.) was used, in the synchronous scanning mode, at the same excitation and emission wavelengths $\left(\lambda_{\text {excitation }}=\lambda_{\text {emission }}\right)$, using a $1 \mathrm{~cm}$ path length quartz cell and $1 \%$ emission attenuation filter in the emission beam.

Molecular modelling has been carried out using HyperChem ver. 7.5. The structures of the CTX and its diazonium ion were optimized using AM1 semiempirical method with restricted Hartree-Fock (RHF) approximation.

\section{Results and Discussion}

\section{Molecular modelling}

Through the primary amino group on the thiazole ring, CTX can react with sodium nitrite, in acidic media, generating a diazonium ion. For the reaction performed at $0-5^{\circ} \mathrm{C}$, in the presence of $\mathrm{KBr}$, a soluble and stable compound was obtained, with an absorption maximum at $504 \mathrm{~nm}$. Molecular modelling studies on the conformational and charge distribution changes indicated for the diazonium ion that an internal charge transfer can take place. The most important changes in the geometry of the molecule are summarized in Table I, as interatomic distances compared with the parent molecule. The most relevant are the decrease of the distance between atoms Nos. 35 and 11 and of the molecule volume from 1273.49 to $1257.45 \AA^{3}$, after diazotization process.

Charge distribution on the ceftriaxone molecule and its diazonium ion are presented in the Figures 1 and 2.

Table I

Interatomic distances computed for ceftriaxone and its diazonium ion

\begin{tabular}{|c|c|c|c|}
\hline Molecule & \multicolumn{3}{|c|}{ Interatomic distances $(\mathbf{\AA})$} \\
\hline Atoms \# & $\mathbf{1 1 - 3 5}$ & $\mathbf{2 1 - 3 0}$ & $\mathbf{2 2 - 3 0}$ \\
\hline Ceftriaxone & 3.33 & 7.25 & 10.81 \\
\hline Ceftriaxone diazonium ion & 2.88 & 7.03 & 10.13 \\
\hline
\end{tabular}




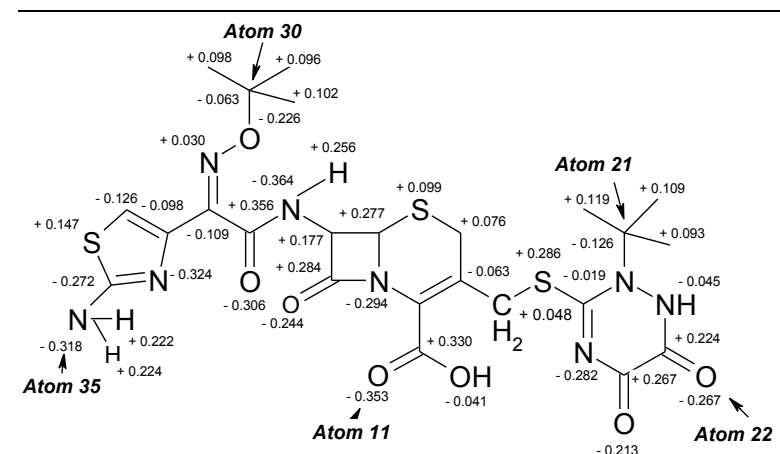

Figure 1.

The structure of ceftriaxone with charge densities

\section{Influence of CTX concentration}

The influence of the CTX concentration was studied in the range $0.15-5 \mathrm{mM}$. The reaction was performed at $0-5^{\circ} \mathrm{C}$, using constant concentrations of $0.18 \mathrm{mM} \mathrm{KBr}, 15 \mathrm{mM} \mathrm{HCl}$ and $20 \mathrm{mM} \mathrm{NaNO}_{2}$. The results indicated that CTX concentration has a strong influence on the solubility of the reaction product. For diluted solutions of CTX within the range $0.15-0.30 \mathrm{mM}$, a stable, soluble diazonium salt of CTX was obtained. For the concentrations higher than $0.3 \mathrm{mM}$ of anhydrous CTX a poorly soluble compound was obtained.

\section{Influence of the type of acid used}

In order to generate the acidic medium for the diazotization reaction, $0.1 \mathrm{M} \mathrm{HCl}$ was used (generally used in diazotization reactions), but also acids that are present in urine in various concentrations, such as oxalic, tartric and citric acids. In all cases a low soluble compound was generated for CTX concentrations greater than $0.3 \mathrm{mM}$. For analytical purposes, higher absorbance was obtained using 15 $\mathrm{mM} \mathrm{HCl}$ in the reaction medium.

\section{Influence of the temperature}

The influence of the environmental temperature was studied in the range $0-40^{\circ} \mathrm{C}$. A soluble, stable reaction product was obtained only for the reaction performed at the temperature between $0-5^{\circ} \mathrm{C}$; at $20^{\circ} \mathrm{C}$, the reaction developed slowly (approx. $1 \mathrm{~h}$ ), the reaction rate increased and the solubility of the diazonium ion decreased with increasing temperature to $40^{\circ} \mathrm{C}$, when the low soluble compound was formed almost instantaneously.

Influence of $\mathrm{NaNO}_{2}$ concentration

The influence of nitrite concentration on the diazotization reaction was studied on solutions prepared with constant concentrations of CTX $(0.18$ $\mathrm{mM}), \mathrm{KBr}(0.18 \mathrm{mM})$ and $\mathrm{HCl}(0.15 \mathrm{mM})$ and concentrations of $\mathrm{NaNO}_{2}$ between 15 and $25 \mathrm{mM}$. Soluble diazonium salt was obtained in all the cases. The amount of $\mathrm{NaNO}_{2}$ in the reaction media does not influence the solubility of the reaction product. Higher absorbance was obtained using 20

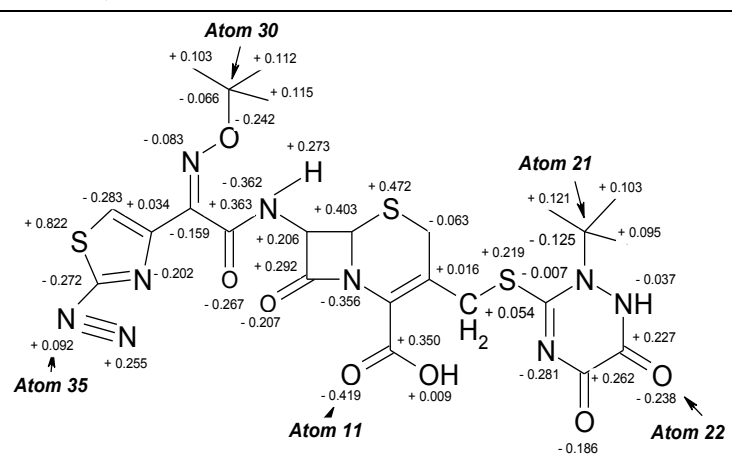

Figure 2.

The structure of diazonium ion with charge densities

$\mathrm{mM} \mathrm{NaNO}_{2}$ and was used for the analytical purpose.

\section{Reaction time}

For the experimental conditions selected for analytical purpose a 5 minutes reaction time of was obtained, the stability of the reaction product being of 15 minutes after preparation. After that, for the solutions with CTX concentration between 0.30 and $0.45 \mathrm{mM}$, a low soluble compound is formed.

The effect of nucleophilic reagents

The diazonium ion is a strong electrophilic chemical species and therefore can be stabilized via the interaction with nucleophilic agents from the reaction medium, such as water molecules, chloride ions, etc. [22]. Thus, the stability of the diazonium-CTX compound in the presence of bromide, chloride and sulphate anions was evaluated. The diazotization reaction was performed on ice and at room temperature, in acidic media, for solutions of 0.18 $\mathrm{mM} \mathrm{CTX}$, at $0-5^{\circ} \mathrm{C}$ and in the presence of $\mathrm{KBr}$, $\mathrm{KCl}$ or $\mathrm{K}_{2} \mathrm{SO}_{4}$. In all cases, the reaction took place instantaneously, and a soluble, stable compound was obtained with or without the presence of nucleophilic agents. A low soluble compound resulted when reaction was performed at room temperature.

In order to detect the volume changes of CTX after its diazotization we used RLS spectra. The RLS spectra were registered in the range $300-800 \mathrm{~nm}$ for CTX, in molecular form, and the diazonium ion obtained in the presence of $\mathrm{KBr}, \mathrm{KCl}$ or $\mathrm{K}_{2} \mathrm{SO}_{4}$.

It was observed that the maxima at 423 and $572 \mathrm{~nm}$ from the CTX RLS spectra are maintained after its diazotization in all the cases $\left(\mathrm{Br}^{-}, \mathrm{Cl}^{-}\right.$and $\left.\mathrm{SO}_{4}{ }^{2-}\right)$, only the intensity of the scattered light increased (Figure 3). This indicates that after dizoatization the dimensions of the molecule remain in the Rayleigh range [12], so no self-aggregation takes place. When $\mathrm{KBr}$ was used, a maximum found in the absorption band $(510 \mathrm{~nm})$ appears, but no significant increase in the intensity of the scattered light was observed. This indicates that the diazonium ion exists in the soluble form as a salt formed with $\mathrm{Br}^{-}$ anion $\left(\mathrm{CTX}-\mathrm{N} \equiv \mathrm{N}^{+} \cdot \mathrm{Br}^{-}\right)$. 


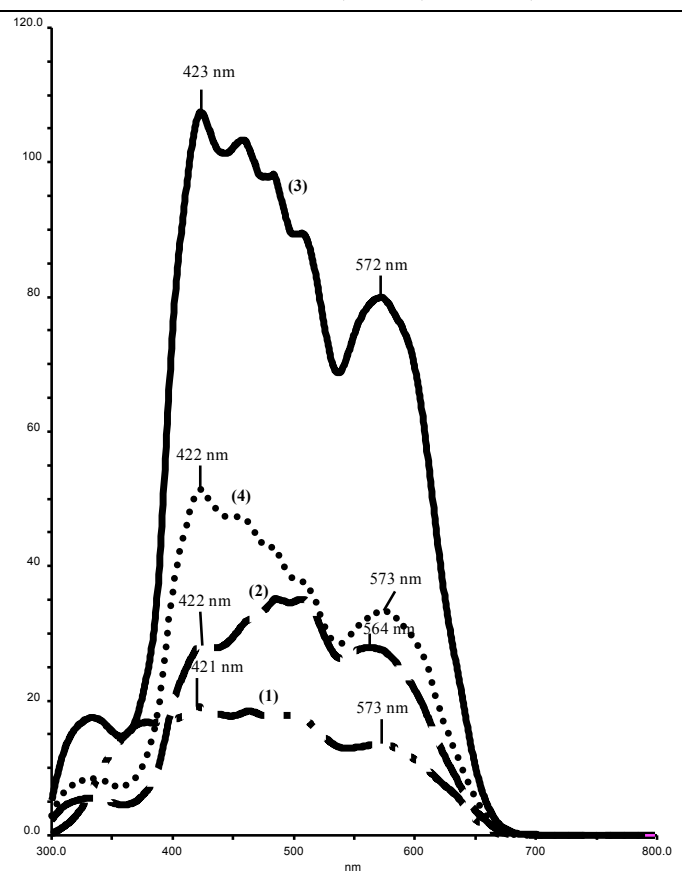

Figure 3.

RLS spectra of (1) CTX $(0.18 \mathrm{mM})$ in molecular form and its diazonium salt obtained in the presence of (2) $\mathrm{KBr}$ (18 mM), (3) $\mathrm{KCl}(18 \mathrm{mM})$ and (4) $\mathrm{K}_{2} \mathrm{SO}_{4}(18 \mathrm{mM})$

\section{Method validation}

For the diazotization of CTX using $\mathrm{KBr}(18 \mathrm{mM})$, $\mathrm{HCl}(15 \mathrm{mM})$ and $\mathrm{Na} \mathrm{NO}_{2}(20 \mathrm{mM})$, at $0-5{ }^{\circ} \mathrm{C}$ validation studies were performed according to Q2(R1) ICH guideline [11]. Validation parameters are resumed in Table II.

Table II

Summary of the validation parameters

\begin{tabular}{|c|c|c|}
\hline Validation criterion & Parameter & Results \\
\hline \multirow[b]{2}{*}{ Linearity } & Regression parameters & $y=0.0046 x-0.231$ \\
\hline & Correlation coefficient & 0.9928 \\
\hline \multicolumn{2}{|c|}{ Detection limit } & $2.52 \mu \mathrm{g} / \mathrm{mL}$ \\
\hline \multicolumn{2}{|c|}{ Quantification limit } & $7.65 \mu \mathrm{g} / \mathrm{mL}$ \\
\hline \multicolumn{2}{|c|}{ Range } & $85-171 \mu \mathrm{g} / \mathrm{mL}$ \\
\hline \multicolumn{2}{|c|}{ Accuracy } & $99.90 \pm 0.55$ \\
\hline \multirow[t]{2}{*}{ Precision } & Repeatability & $\mathrm{RSD}=0.89 \%$ \\
\hline & Reproducibility & $\mathrm{RSD}=0.95 \%$ \\
\hline
\end{tabular}

The proposed method was applied with good results to the assay of CTX in pharmaceutical dosage forms (powder for injection).

Potential medical implications of the reaction of CTX with sodium nitrite

From the reaction of CTX with sodium nitrite, stable and soluble compound results in the experimental conditions presented at the Validation method section. Because any deviation from these conditions results in a sparingly soluble compound, medical implications of this reaction are considered. Published data state that the average concentration of CTX in urine two hours after $2.0 \mathrm{~g}$ of i.v. bolus was about $4 \mathrm{mM}$ [6]. That is the main reason of which the experiments were performed in the range higher than $0.3 \mathrm{mM}$, up to $5 \mathrm{mM} \mathrm{CTX}$. The concentration of the urinary nitrite has a great variability, being correlated with the NO metabolism, food intake and pathological conditions; in urinary infections nitrite concentrations generally increase [14]. Therefore, can be considered that during CTX treatment, under certain physiological conditions (low urinary $\mathrm{pH}$, high fever - characteristic for the urinary infections), in the presence of urinary nitrite, the sparingly soluble compound formed in the reaction with CTX, can act as centres of crystallization, thus predisposing to nephrolithiasis. The observations are in good agreement with the literature data that indicate high concentrations of CTX as the determinant factor for predisposition to nephrolithiasis [24]. 


\section{Conclusions}

The interaction between ceftriaxone and sodium nitrite was investigated using molecular modelling, UV-Vis absorption and resonance light scattering spectrophotometry. Experimental data indicated the formation of a soluble diazonium salt of ceftriaxone using well-defined experimental conditions namely: CTX concentrations below $0.30 \mathrm{mM}, 20 \mathrm{mM}$ $\mathrm{NaNO}_{2}, 18 \mathrm{mM} \mathrm{KBr}$ and $15 \mathrm{mM} \mathrm{HCl}$, at temperatures of $0-5^{\circ} \mathrm{C}$. Molecular modelling coupled with spectral data suggest the internal charge transfer for the stabilization mechanism of the diazonium ion. A new validated visible spectrophotometric method for CTX assay was developed. An interesting observation was that deviations from the above-mentioned conditions lead to a sparingly soluble reaction product, especially at higher concentration of CTX and temperatures above $5^{\circ} \mathrm{C}$. This can be used to investigate the possibility that the reaction between ceftriaxone and nitrites could possibly trigger nephrolithiasis.

\section{References}

1. Adegoke OA, Quadri MO, Novel spectrophotometric determinations of some cephalosporins following azo dye formation with p-dimethylaminobenzaldehyde. Arabian J Chem., 2016; 9(2): S1272-S1282.

2. Chambers HF, Moreau D, Yajko D, Miick C, Wagner C, Hackbarth C, Kocago S, Rosenberg E, Hadley K, Nikaido H, Can Penicillins and Other bLactam Antibiotics Be Used To Treat Tuberculosis?. Antimicrob Agents Chemother., 1995; 39(12): 26202624.

3. Clarke EGC, Clarke's analysis of drug and poisons in pharmaceuticals, body fluids and postmortem material. Fourth Edition. London. The Pharmaceutical Press, 2011; pp: 1061-1062

4. Cochat P, Cochat N, Jouvenet M, Floret D, Wright C, Martin X, Vallon JJ, David L, Ceftriaxone-associated nephrolithiasis. Nephrol Dial Transplant., 1990; 5(11): 974-976.

5. Chutipongtanate S, Thongboonkerd V, Ceftriaxone crystallization and its potential role in kidney stone formation. Biochem Biophys Res Commun., 2011; 406(3): 396-402.

6. Cong X, Gu X, Sun X, Ning B, Shen L, Possible function of urinary $\mathrm{pH}$ and citrate on the ceftriaxone-induced nephrolithiasis. Urology, 2014; 83(1): 63-67.

7. Florea M, Ilie M, Ion-pair spectrophotometry in pharmeceutical and biomedical analysis: challenges and perspectives. In spectroscopic analyses developments and applications. InTech, Croatia, 2017; pp:173-192

8. Florea M, Monciu CM, Ilie M, Resonance Rayleigh scattering study of streptomycin - Congo red ionic association in view of analytical application. Farmacia, 2014; 62(2): 318-328
9. Florea M, Monciu CM, Ilie M, Determination of nimesulide by ion pair high-performance liquid chromatography using tetrabutylammonium as the counterion. Anal Lett., 2015; 48: 328-339.

10. Fu S, Liu Z, Liu S, Yi A, Study on the resonance Rayleigh scattering, second-order scattering and frequency doubling scattering spectra of the interactions of palladium (II) - ceftriaxone chelate with anionic surfactants and their analytical applications. Talanta, 2008; 75(2): 528-535.

11. ICH Q2(R1). Validation of analytical procedures: Text and methodology Q2(R1), ICH Harmonized Tripartite Guideline, International Conference on Harmonization of Technical Reguirements for Registration of Pharmaceuticals for Human Use, Incorporated in November, 2005. Geneva: ICH Secretariat

12. Yguerabide J, Yguerabide EE, Light-scattering submicroscopic particles as highly fluorescent analogs and their use as tracer labels in clinical and biological applications. Anal Biochem., 1998; 262: 137-156.

13. Li X, Li H, Li S, Zhu F, Kim DJ, Xie H, Li Y, Nadas J, Oi N, Zykova TA, Yu DH, Lee MH, Kim MO, Wang L, Ma W, Lubet RA, Bode AM, Dong Z, Dong Z, Deftriaxone, an FDA-approved cephalosporin antibiotic, suppresses lung cancer growth by targeting Aurorra B. Carcinogenesis, 2012; 33(12): 2548-2557.

14. Machha A, Schechter AN, Dietary nitrite and nitrate: a review of potential mechanisms of cardiovascular benefits. Eur J Nutr., 2011; 50(5): 293-303.

15. Mohkam M, Karimi A, Gharib A, Daneshmand H, Khatami A, Ghojevand N, Sharifian M, Ceftriaxone associated nephrolithiasis: a prospective study in 284 children. Pediatr Nephrol., 2007; 22(5): 690694.

16. de Moor RA, Egberts AC, Schröder $\mathrm{CH}$, Ceftriaxone-associated nephrolithiasis and biliary pseudolithiasis. Eur J Pediatr., 1999; 158(12): 975977.

17. Owens HM, Dash AK, Ceftriaxone sodium: Comprehensive Profile. Profiles of Drug Substances, Excipients and Related Methodology. Brittain HG, 2003; 30: 21-58.

18. Rais C, Taerel AE, Ștefănescu E, Brumărel M, Safta V, Adauji S, Priscu V, Soroceanu V, Epidemiological aspecs of tuberculosis in adults in Romania fersus Republic of Moldova. Farmacia, 2016; 64(4): 643-650

19. Sekhar C, Manohara YN, Rao S, Rajut A, Validated spectrophotometric methods for the estimation of ceftriaxone in pharmaceutical preparations. Asian J Chem., 2006; 18(4): 25232527

20. Štastnẏ M, Vulterin J, Volf R, Maršolek P, Determination of aromatic amines by the method of direct injection enthalpimetry. Chem zvesti., 1979; 33(3): 410-419

21. Taerel AE, Soroceanu V, Rais C, Trends in the evolution of the annual classified list of medicines between 1989-2012. Farmacia, 2013; 61(5): 948956 
FARMACIA, 2018, Vol. 66, 6

22. Tsikas D, Analysis of nitrite and nitrate in biological fluids by assays based on the Griess reaction: Appraisal of the Griess reaction in the Larginine/nitric oxide area of research. $J$ Chromatogr B., 2007; 851: 51-70.

23. Uri JV, Jain TC, Colorimetric detection and spectrophotometric determination of the aminothiazolyl- alkoxyimino $\beta$-lactams. $J$ Antibiot., 1986; 39(5): 669-675.

24. Wang S, Huang X, Xu Q, Xu T, Research progress of mechanisms of ceftriaxone associated nephrolithiasis, Mini Rev Med Chem., 2017; 17(17): 1584-1587. 